\title{
Labour Law Beyond National Borders: Major Debates in 2016
}

Steven L. Willborn, Eri Kasagi and Sebastián de Soto Rioja

\section{(2) OpenEdition}

1 Journals

Electronic version

URL: https://journals.openedition.org/rdctss/2577

DOI: $10.4000 /$ rdctss. 2577

ISSN: 2262-9815

Publisher

Centre de droit comparé du travail et de la sécurité sociale

Printed version

Date of publication: 1 December 2017

Number of pages: 286-307

ISSN: $2117-4350$

\section{Electronic reference}

Steven L. Willborn, Eri Kasagi and Sebastián de Soto Rioja, "Labour Law Beyond National Borders:

Major Debates in 2016", Revue de droit comparé du travail et de la sécurité sociale [Online], 4 | 2017 ,

Online since 01 November 2021, connection on 04 December 2021. URL: http://

journals.openedition.org/rdctss/2577 ; DOI: https://doi.org/10.4000/rdctss.2577

\section{(c) $(1)$}

Revue de droit comparé du travail et de la sécurité sociale est mise à disposition selon les termes de la Licence Creative Commons Attribution - Pas d'Utilisation Commerciale - Pas de Modification 4.0 International. 


\section{STEVEN L. WILLBORN \\ Spencer Professor of Law, University of Nebraska College of Law, USA.}

\section{ERI KASAGI}

Researcher at CNRS, Centre for Comparative Labour and Social Security Law (COMPTRASEC), UMR5114 CNRS - University of Bordeaux, France

\section{SEBASTIÁN DE SOTO RIOJA}

Catedrático de Derecho del Trabajo y de la Seguridad Social, Universidad Pablo de Olavide (Seville)-España

\section{LABOUR LAW BEYOND NATIONAL BORDERS: MAJOR DEBATES IN 2016}

The International Association of Labour Law Journals (IALLJ or the Association) is a consortium of 29 journals from around the world. ${ }^{1}$ Every year since 2012, a group of editors have collaborated to provide a review of the major themes that appeared in member journals. This is the review of the more than 700 articles that were published in the Association's journals during 2016.

As one would expect, the articles covered virtually the entire gamut of possible labor and employment topics. Working with an exceptional team of editors, ${ }^{2}$ we were able to sort the articles into subject-matter categories. For this review, we selected three major themes that gathered lots of attention: Effective enforcement of labour laws; the challenges presented by the changing nature of employment; and wages, poverty and income issues. ${ }^{3}$

1 The full list of the IALLJ member journals can be found here: www.labourlawjournals.com Abbreviations for the journals used in this article can be found at the end of the article.

2 The authors were assisted by a team of colleagues who listed, reviewed, categorized, and (where necessary) translated all the articles. The members of this team were Gian Guido Balandi, Antonio Pedro Baylos Grau, Marialaura Birgillito, Silvia Borelli, Matteo Borzaga, Isabelle Daugareilh, Manuel Garcia-Muñoz Alhambra, Eva Maria Hohnerlein, Barbara Kresal, Sandrine Laviolette, Miguel Rodríguez-Piñero Royo, Anna Rita Tinti, and Jesús Cruz Villalón.

3 This review is the joint product of the authors, but Sebastián de Soto Rioja was primarily responsible for section A, Steve Willborn for section B, and Eri Kasagi for section C. 


\section{- EFFECTIVE ENFORCEMENT OF LABOUR LAWS}

\section{A - WHAT DOES IT MEAN?}

Ever since the beginning of Labour Law - or "Législation Ouvrier," "Legislazione Operaia," "Factory Acts," or "Leyes de Fábrica" - it has been necessary to make sure its legal mandates were respected, so as to guarantee the actual fulfilment of its main purposes: maintaining peace and furthering social justice. Enforcement must be especially effective for those essential rights deemed to underlie real public order (ius minimum), insofar as they affect workers' livelihood, their health and even their own lives; in short, their dignity as human beings. Labour Law, therefore, is not merely a specific field of law; it adopts critical positions with regard to civil law or the common law and requires decisive state interventions to secure one of the basic pillars on which all democratic systems are based.

These defining traits explain why Labour Law is prominent among broad policy goals; its scope goes beyond mere economics and the role of the labour force as a factor of production. Centuries-old specialized ministries or agencies in governments all over the world as well as in different international organizations bear witness to this fact.

A special administrative police have in fact been specifically set up to guarantee the effective application of labour standards, such as the labour and social security inspectorates. These bodies of civil servants are present in more than one hundred sovereign states. ${ }^{4}$ Their main trait is their intimidating power to report and/or sanction detected infractions, thus representing the front line of combat in this specific battle.

Control and administrative intervention, however, are not the law's only answer to this "social question." As shown by one of the first universal labour law experts, Anton Menger, ${ }^{5}$ for social legislation to be truly effective, it needs the necessary judicial complement, because ultimately, subjective rights only become peremptory (ius cogens) when their purpose and their foreseen legal consequences are fulfilled. Hence, labour disputes usually receive a singular treatment in all judicial systems, in most cases leading to a set of distinct special procedures, and even a separate civil, common or even administrative (when there is one) jurisdiction. These processes aim at guaranteeing: i) ease of access, often by means of gratuities for workers and the recognition of trade union rights of representation; ii) greater simplicity of procedures, with mainly oral proceedings, sometimes dispensing with lawyers; and iii) swift or prompt resolution, given that what is usually at stake in the litigation is the very sustenance of workers and their dependent family units. ${ }^{6}$

$4 \quad$ http://www.iali-aiit.org, website of International Association of Labour Inspection.

5 Author of The Right to the Whole Produce of Labour (english version, London-New York, 1899) is best known for his critical work Das bürgerliche Recht und die besitzlosen Volksklassen: Eine Kritik des Entwurfs eines bürgerlichen Gesetzbuches für das deutsche Reich, Tübingen, ed. H. Laupp, 1890. I quote from the spanish translation, Derecho Civil y los pobres, (Madrid, 1898), which notes among many other items the need to adapt procedural law to remedy the traditional "abstention" and "passivity" of civil judges in matters of private law and encouraging greater public involvement.

6 Valdés Dal-Ré, F., "Un examen comparatista de las jurisdicciones sociales: la convergencia en los principios," DRL, 2017-6, p. 473. 
Unsurprisingly, these are constantly recurring issues in the scientific literature related to this body of law; and, to an even greater extent, if we include the range of strictly legal procedures that respond to the call for "effectiveness" or "efficiency" of labour standards. One example is including a greater number of subjects deemed financially liable when several companies are involved; another illustration is the extension of the principle of solidarity of sentences and not that of mere subsidiarity, which operates only in the case of insolvency of the main debtor; or the creation of public funds that guarantee that subjects ultimately receive the necessary economic benefits to which they are entitled.

Due to the effects of globalization and the fact that workers are considered as full citizens, such legal procedures must also include the internationalization of labour laws and raising them to the category of basic human rights. These latter solutions introduce, however, additional problems, as they must coexist with realities such as the principle of territoriality and consequently, multiple charters of rights applicable within the same territory, sometimes even within the same nation. Let us remember what this entails, such as having to harmonize legal formulations and different jurisprudential constructs.

Furthermore, real working conditions are, in fact, usually defined outside the realm of formal law, through supplementary sources such as collective agreements or even individually negotiated work contracts. Thus, the effectiveness of collective and private negotiations must also be guaranteed, and their very existence requires a basic system of liberties, i.e. freedom of association and of collective action, including the right to strike.

The first predictable consequence is that more than a hundred of all the articles published by our association in 2016 (i.e. one in seven) refer directly and explicitly to problems in enforcing labour standards. Labour standards are no longer interpreted here in their capacity to organize behaviour and transform society in the ontological sense of what "should be," following idealistic principles of social and redistributive justice. ${ }^{7}$ This would indeed be difficult to assess. The term is understood rather as a set of legal mechanisms and institutions that are meant to ensure that the obligatory legal consequences foreseen by regulatory mandates have real repercussions and do not become merely formal declarations.

Nevertheless, such a broad understanding of the issue can obviously lead to overlap with the other two subjects selected for this article, especially given that Labour Law is under constant pressure from commercial law and the postulates of the liberal economy. The latter leads to a practically universal phenomenon of "flight" or "escapism" from social

7 Articles on these topics were also very present in 2016 given that it was a time of major legal reform and big economic transformations. Representative works include: Caruso, B., "Impresa, lavoro, diritto nella stagione del Jobs Act," DLRI, 2016, iss. 150, p. 255; Gesualdi Facteau, D., "De I'usage du droit du travail: une contribution théorique aux études portant sur l'effectivité du droit," RDCTSS, 2016-1, p. 16; Hohnerlein, E.Ma, "Soziale Rechte für Drittstaatsangehörige: Zugang zu Sozialleistungen aus unions- und menschenrechtlicher Perspektive," ZIAS, 2016-1, vol.30, p. 47; Mariucci, L., "Culture e dottrine del giuslavorismo", LD, 2016-4, p. 585 and the essays published in the chapter "Culture e dottrine del giuslavorismo" of the same issue; Rodríguez-Piñero y Bravo-Ferrer, M., Casas Baamonde, M.E., "El derecho del trabajo a debate", DRL, 2016-3, p. 189; Romagnoli, U., "Momenti di storia della cultura giuridica del lavoro," LD, 2016-1, p. 3; in the same issue, Perulli, A., "L'idea di diritto del lavoro, oggi," p. 17; Supiot, A., "What International Social Justice in the twenty-first century?," BCLR, 2016, iss. 92, p. 1 (available in French and Spanish at http://www.college-de-france.fr/site/alain-supiot/articles-en-ligne.htm); Veneziani, B., "Del contenuto essenziale dei diritti dei lavoratori: spunti per una ricerca," DLM, 2016-2, p. 229. 
legislation, that is, its scope of application, the concept of work and that of the protected worker, need to be continually redefined as the consequence of any new construction taking place in the world of business organization. ${ }^{8}$ This means that, to be successful, labour legislation needs to be almost entirely reshaped.

To avoid this risk of overlap, we will limit ourselves to reviewing only issues that are indubitable and strictly related, in particular: public intervention in labour relations systems; procedures for resolving labour disputes; difficulties in applying international and supranational legal standards; and, finally, the effectiveness of collective bargaining.

\section{B - PUBLIC INTERVENTION IN LABOUR RELATIONS}

Studies on how labour inspection is designed and operates are diverse and widespread throughout the world. They focus either on systems that are applicable in specific countries, or they are multi-country analyses using comparative law methods. This second category is particularly worthy of mention as the nature of these studies is more conclusive and they shed light on the wide range of functions assigned to administrative structures. ${ }^{9}$ Interestingly, these bodies do not always act solely and exclusively as formal agents in charge of sanctioning legal infractions by imposing fines; they also provide advice and instruct companies by issuing recommendations, or even by acting as mediators in certain types of conflicts. ${ }^{10}$

Other articles, however, emphasize how digitalization and advances in new technologies can also help to control business activity in all fields of interest, including social security, and cut down on large amounts of informality, so typical of certain labour relations systems. One example is the use of electronic records and databases that have been specifically created ex novo for that purpose. ${ }^{11}$

Another related issue is that of the status of whistleblowers, particularly when whistleblowers are affected workers. This is a relevant subject not only because it requires decisive public intervention but also because it is based on anonymous reporting, a traditional technique for controlling systems. Workers must be protected by any relevant

8 The so-called "co-work" (not to be confused with "crowd-work") is a good example of this practice, a new concept inside the broad term "gig-economy" or "collaborative/sharing economy" although very different from most of these concepts. It is a model expressly unauthorized in France by the Cour de Cassation, qualified as illicit assignments (cession) of workers. Auzero, G., "Co-emploi," RDT, 2016-1, p. 27; Pagnerre, Y., "Critère du coemploi," RDT, 2016-3, p.175. For a very interesting contribution, see the BCLR, special monograph, 2016, iss. 94, about "New Forms of Employment in Europe," which analyzes this issue in more than 38 countries.

9 Suzuki, T., "International Trends in Systems for Inspection of Labor Law Violations," JLR, 2016-4, vol.13 (Special Edition: Illegal Labour), pp. 83; in the same issue, but centered on domestic law, see Yamakawa, R., "Policy measures to tackle violations of labor and employment laws in Japan," p. 98.

10 Vid. Fine, J., "Afterword: The Franco-Iberian Model from the U.S. Perspective," CLLPJ, 2016-2, vol. 3 , p. 397, who points out this specific character in a special and interesting issue with contributions from Argentina, Brazil, France, Italy, Quebec and Spain.

11 See Bernardo Alvarado, J., "¿En el partidor?," AL, 2016-472, vol. XL, p. 6, for a critical view of SUNAFIL (Superintendencia Nacional de Fiscalización Laboral); in the same issue, see Vilela, A., "Problemática actual en el cumplimiento de la función inspectiva," p. 12. See also, Nicolás Bernad, J.A., "Actas de liquidación fundadas en contravenciones de normativa extralaboral: evolución histórica y jurisprudencial," RDS, 2016, n 74, p. 87. 
duty of secrecy and confidentiality, as well as by guaranteed preservation of employment. ${ }^{12}$ The figure of whistleblower originally emerged as an instrument in a wide range of fields, such as the fight against political corruption and serious crimes endangering public health and safety. It should also have significant effects in labour issues, especially when the complainant is a private sector worker for whom available general witness protection is often insufficient, and who does not benefit from public servant guarantees. ${ }^{13}$

These conditions were established in one of the latest reports of the Implementation Review Group (IRG). The IRG acts on behalf of the Conference of States Parties (COSP), which endorsed the United Nations Convention Against Corruption (UNCAC) - signed on 3 October 2017 by 140 countries - whose article 33 says:

Each State Party shall consider incorporating into its domestic legal system appropriate measures to provide protection against any unjustified treatment for any person who reports in good faith and on reasonable grounds to the competent authorities any facts concerning offences established in accordance with this Convention.

From this broad perspective of public intervention or concern about working conditions in the overall labour relations system, it is worth highlighting the publication of other types of work, no doubt as interesting, such as the analysis of the impact of the participation of the private sector in public action. This study includes a variety of articles ${ }^{14}$ examining the type and level of control that public bodies may carry out, not as an authority but as a contracting party, according to the worker regime applied in the case of companies directly providing essential public services. Examples are subsidized health or education, as well as many other instrumental or transversal activities that take place in the public sector as a whole (cleaning, maintenance, security, etc.). These articles examine aspects of collective rights and rights to information, compliance with health and safety standards, as well as more specific issues such as guarantees of effective payment of wages ${ }^{15}$ or the legality of the use of temporary employment in the execution of these contracts. ${ }^{16}$

12 Zimmermann, H., "Zur Problematik anonymer Arbeitnehmerbescwerden," AuR, 2016-6, vol. 64, p. 226. From the perspective of Directive 2009/52/EC of the European Parliament and of the Council of 18 June 2009 providing for minimum standards on sanctions and measures against employers of illegally staying third-country nationals, Giaconi, M., "Le politiche europee di contrasto al lavoro sommerso. Tra (molto) soft law e (poco) hard law," LD, 2016-3, p. 439, analyzes a similar protection in the field of illicit work. On this Directive and in the same issue but pointing out the problem of translating some technical words, because of the difference between illegal vs. irregular job, see Varva, S., "Undeclared work e Unione europea, ultimo atto: una "piattaforma europea" per contrastare il lavoro sommerso," p. 461.

13 On whether this protection is effective in all countries, especially in Germany, see Fischer-Lescano, A., "Internationalrechtliche Regulierung des Whistleblowing. Anpassungsbedarf im deutschen Recht (Teil1-2)," AuR, 2016-1/2, vol. 64, pp. 4 \& 48, respectively.

14 For all, see Cruz Villalón, J., "Claves laborales de la participación privada en la actuación pública," $T L, n^{\circ} 135 / 2016$, p.13.

15 Sáez Lara, C., "Garantías y responsabilidades en materia salarial," TL, n 135/2016, p.345.

16 Rodríguez-Piñero Royo, M., "Gestión privada, contratación temporal y calidad en el empleo," $T L$, $n^{\circ} 135 / 2016$, p. 111. 


\section{C - LABOUR DISPUTE PROCEEDINGS}

We will not attempt to be exhaustive, and will not reflect the entire range of problems generated by judicial rulings, particularly those of a strictly formal or procedural nature. ${ }^{17}$ We will also expressly leave aside issues relating to the extended systems of extrajudicial resolution of conflicts. It is worth noting the existence of interesting theoretical studies and reflections such as those examining the important role of judges in a constitutional democracy when assessing the scope and significance of basic collective rights, insofar as they become a criterion to evaluate the entire democratic system. ${ }^{18}$

From a completely different perspective, we also find presentations of statistical results on national judicial practice. ${ }^{19}$ These are very useful to shed light on the fulfilment of the main purposes assigned to procedural systems. They permit us to evaluate, for example, i) the average resolution time of proceedings; ii) the activity of each type of court, i.e. being able to know both work volume and the meaning of sentences; iii) the profile of the claimants; and, of course, iv) the matters or types of cases being prosecuted.

Another category of relevant works are those centering on the existence and even the denunciation of significant changes in the system as a result of implemented reforms. The reports that stand out in this group are those relating to the impact of the approval in the

17 For specific matters, see Pogorelčnik Vogrinc, N., "Razlogi za obnovo postopka v individualnih delovnih sporih," E\&E, 2016-2/3, vol. XVI, p. 283, about an extraordinary judicial review procedure permitting an open-ended review of matters such as substantial violation of the procedure, criminal offences, and new facts and new evidence. In the same issue, Kresal, B., "Obstoj delovnega razmerja kot predhodno vprašanje v delovnih sporih," discusses issues relating to the existence of an employment relationship as a preliminary issue in labour disputes, p. 217-240. Another very singular questions asked by Barnard, C., "Enforcement of Employment Rights by EU-8 Migrant Workers in Employment Tribunals," ILJ, 2016-1, vol.45, p. 28, is how these workers can even begin to finance the costs of the trial. Cf., too, Fotinopoulou Basurko, O., "La inmunidad de jurisdicción y los contratos de trabajo en la LO 16/2015," RDS, n 73/2016, p.69.

18 Paquette, J.R., "The Call for Deference in Labour Relations: An Answer to Justice Rothstein," CL\&ELJ, 2016-2, vol. 19, p. 101. On the role of judges in shaping Italian Labour Law see Ballestrero, M.V., "Il ruolo della giurisprudenza nella costruzione del diritto del lavoro", LD, 2016-4, p. 761 and the essays published in the chapter "Il diritto del lavoro vivente: la giurisprudenza" of the same issue. On the role of the Spanish Suprime Court see Baylos Grau, A., "La "jurisprudencia ordinaria" del Tribunal supremo", LD, 2016-4, p. 823. For interesting comments on the role of a particular judge (Antonin Scalia) in the US system, especially on the future of so-called "agency shop clauses," see "Verso la fine del sindacato americano? La costituzionalità dell'obbligo di pagamento del contributo sindacale al vaglio della Corte Suprema degli Stati Uniti d'America," DLRI, 2016-4, vol. 152, p.759. See also, Szymanski, "Scalia's shadow: the Friedrichs Case and the fate of the American labor movement," same iss., p.761. For more on the role of judges, see Golding, G., "The Role of Judges in the Regulation of Australian Employment," IJCLLIR, 2016-1, vol. 32, p. 69. See also, Nogueira Guastavino, M., "La libertad sindical negativa en Estados Unidos," DRL 2016-4, p. 374.

19 For data and analysis in Japan and Germany, see Hamaguchi, K., "Comparative Analysis of Employment Dispute Cases Resolved by Labor Bureau Conciliation, Labor Tribunals and Court Settlement," JLR, 2016-2, vol.13, p. 119; and Grotmann Höfling, G., "20 years of labour courts' joint statistics - an examination of basic points," AuR, 2016-11, vol. 64, p. 407. By the same author and in the same review, see Evans, C.W., "Die Arbeitsgerichchtsbarkeit 2015 im Lichte der Statistik," 2016-12, p. 497, which shows that the average resolution time is less than a year, appeals have declined and are mostly ignored (55\%), and procedures initiated by employers have increased. It also highlights how the legal process is usually performed by lawyers and rarely by works committees or directly by employees. 
United Kingdom of the Trade Union Act $2016,{ }^{20}$ along with a number of other austerity measures. One criticism of the Act, among others, is that it led to imposing judicial fees in these types of proceedings; but above all, because of employers' newfound ability to use the wide range of resources offered by common legislation, including the concept of liability for damages (tort) as a possible response to strikes or other collective actions. ${ }^{21}$

Undoubtedly, our last word in this chapter must go to the foremost legal category of all, the fundamental rights, that of people's authentic basic rights. The fact that the Bill or Charters of Rights raise many basic labour guarantees to this category to ensure their effective fulfilment undoubtedly stems directly from the constitutionalization of a large share of Labour Law. ${ }^{22}$ This means that all the techniques of approach and interpretation of constitutional norms apply, including balancing, preventive suspension of effects, rules of reversal of the burden of proof and nullity of what has been done. ${ }^{23}$

The list of references becomes very extensive if we include all anti-discrimination protections, either due to distinguishing criteria when reaching the prohibited result (gender, ${ }^{24}$ race, religion, nationality, age, disability, ${ }^{25}$ etc.), or because of the particular employment issue at hand, although most cases are related to dismissal. ${ }^{26}$

\section{- APPLYING INTERNATIONAL AND SUPRANATIONAL REGULATIONS}

This matter is closely linked to the topic above as international and supranational standards provide all state systems with new lists of rights of a higher order, whether endowed with the ultimate status of human rights or of fundamental social rights. The bibliography reflects profound coordination difficulties in applying the constructions elaborated by different acting bodies around the world or at a continental level compatible with those of each internal legal framework ${ }^{27}$. These problems are sometimes even linked to

20 For analysis of a similar case, because of Macron's reform in France, see Marshall, D. and Henry, M., "Vers une normalisation de la justice prud'homale?," RDT, 2016-7/8, p. 457. See also, Martin, P., "La reforma laboral en Francia," TL, n 134/2016, p. 45.

21 Bogg, A., "Beyond Neo-Liberalism: The Trade Union Act 2016 and the Authoritarian State," ILJ, 2016-3, vol.45, p. 299. For a general view of the matter, see "Book Review: New Frontiers in Empirical Labour Law Research," ILJ, 2016-2, vol. 45, p. 263. See also, Cabrelli, D., "Liability and Remedies for Breach of the Contract of Employment at Common Law: Some Recent Developments," ILJ, 20162, vol. 45, p. 207.

22 Valdés Dal-Ré, F., "Constitucionalismo laboral europeo y protección multinivel de los derechos laborales," DRL, 2016-2, p. 91. By the same author and in the same review (co-editor), see "Las libertades de reunión y de asociación en el CEDH (ECHR)," DRL, 2016-4, p. 301.

23 Ballestrero, M.V., "Tra discriminazione e motivo illecito: il percorso accidentato della reintegrazione," DLRI, 2016-2, vol. 38, p. 231.

24 Heron, A., "Effective protection of pregnant women at work: Still waiting for delivery?," AJLL, 20161, vol. 29, p. 24.

25 Varva, S., "Promozione dei soggetti svantaggiati negli appalti pubblici. La regolazione locale e la direttiva 2014/24/UE,",LD, 2016-1, p. 53.

26 Benecke, M., "AGG und Kündigungsschutz - da BAG und die diskriminierende Kúndigung," AuR, 2016-1, vol.64, p. 9, discussing the role of the Federal Labor Court on discriminatory dismissals.

27 On the horizontal direct effect of the EU principle of non-discrimination in Spain see Ballester Pastor, M.A., "La efectividad en España de la normativa antidiscriminatoria de la Unión Europea: la dimensión desconocida de las cláusulas horizontales)», DRL, 2016-10, p. 968. 
the consciously blurred or overly general formulations used when writing these standards, hence the importance of programmes for technical improvements of regulations such as REFIT. ${ }^{28}$

Another consequence is, of course, that many national bodies continue to express reservations when they are compelled to somewhat modify their established constructions, acting as zealous guardians of the idea of State sovereignty. ${ }^{29}$

This field has grown considerably in recent years because legal actors need new sources of arguments on which to base their claims, particularly when they witness that their demands are being rejected at a national or internal level, as a consequence of the interpretation made by the jurisprudence of the State itself, or because of the impact of legal reforms. This leads them to search for fresh legitimacy in international regulations. ${ }^{30}$

For obvious reasons, European or European community social regulations are a central topic for many articles. This is not only because these are the raison d'être of some journals or because they provide explicit content to their title, but also because they address matters relating to the other half of our field, that is, legislation on social protection or social security. There are, nevertheless, further explanations. The supranational nature of community regulations are also reflected in the ECJ's constant defence of its own autonomous and distinctive basic concepts in the field, so it is up to national systems to adapt to them and not the other way around. ${ }^{31}$ Thus, there is a constant source of nuance and new alignments relating to almost all issues and, thus, continual reasons for study and research. Specifically, the debate on the application to Spanish law of the rules on non-discrimination between temporary jobs in order to compensate for their termination and the direct effectiveness of Directive 99/70, has had a great relevance in that country after the ECJ's decisions ${ }^{32}$.

28 The Commission's Regulatory Fitness and Performance (REFIT) programme ensures that EU legislation delivers results for citizens and businesses effectively, efficiently and at minimum cost. REFIT aims to keep EU law simple, remove unnecessary burdens and adapt existing legislation without compromising on policy objectives. Schömann, I., “Mieux légiférer dans I'Union Européenne: simplifier ou dénaturer l'acquis communautaire ? Analyse critique d'une initiative de la Commission au regard du Droit du travail," RDCTSS, 2016-1, p. 6

29 Villanueva, F., "La définition du niveau de négociation collective au Pérou : un processus singulier d'appropriation des décisions du Comité de la liberté syndicale de l'OIT par le Tribunal constitutionnel,» RDCTSS, 2016-1, p. 70 ; Anderson, G.,"The Common Law and the Reconstruction of Employment Relationships in New Zealand," IJCLLIR, 2016-1, vol. 32, p. 93.

30 Cabeza Pereiro, J., "Algunas reflexiones a la vista del asunto TYCO sobre el concepto 'tiempo de trabajo,"' DRL, 2016-1, p. 36.

31 Creighton, B., "Who Is a 'Worker' in International Law?," CLLPJ, 2016-3, vol. 37, p. 691.

32 Casas Baamonde, $M^{a} E$ and Rodriguez-Piñero y Bravo Ferrer, M. "La igualdad de trato en la contratación temporal, el derecho de los trabajadores interinos a indemnización por la finalización de su contrato por causa objetiva y los encadenamientos abusivos de contratos y relaciones de servicios temporales en las Administraciones públicas españolas. Las sentencias del Tribunal de Justicia de la UE de 14 de septiembre de 2016", DRL 2016-9, p. 838; Pérez Rey, J. "Para una reformulación de nuestro modelo de contratación temporal: reflexiones sobre las consecuencias de la Sentencia Porras en nuestro ordenamiento y la eficacia de la Directiva 99/70", RDS n76/2016, p. 219. 
Issues covered are diverse and are all of great interest, such as: international migration; ${ }^{33}$ the posting of workers ${ }^{34}$ in the framework of the provision of services; requirements of temporary contracts; ${ }^{35}$ consequences other than nationality as jurisdiction abroad, ${ }^{36}$ not to mention other topics described above or that will be examined in the following sections. The latter were given special attention in many of the studies carried out during 2016.

\section{E - EFFICIENCY OF COLLECTIVE BARGAINING}

As pointed out from the start, when referring to the effectiveness of labour standards, one cannot avoid mentioning the most unique defining characteristic of all Labour Law, i.e. the recognition of collective agreements as the main source of regulation of working conditions ${ }^{37}$. However, the existence of genuine collective agreements obviously depends on something more than mere recognition of that distinct formal instrument. ${ }^{38}$ Authentic collective autonomy depends on the existence of freedom of association and the right to collective action, and in particular, the right to strike. Two main axes, united by common criteria mentioned previously, help to illustrate our main concerns in this matter. That should not mean ever forgetting the role of individual autonomy. ${ }^{39}$

First, we refer to the set of reforms carried out in some specific countries insofar as they reveal important trends. This is the case, for example, in Spain, where the impact of some of the major changes introduced in 2012 on collective agreement effectiveness, concerning the intangibility of agreement content and its scrupulous application, is still under study. This amounts to prohibiting modifications by subjects other than negotiators themselves. The new law has now enabled this by establishing mandatory arbitration for parties in cases of corporate crisis. In these situations, the Arbitral Award sets new temporary applicable working conditions. ${ }^{40}$ Something similar happened in Italy during the 2015 reforms, although to a much lesser extent. This means that implementing a corporate collective agreement is prioritized over a national collective agreement, at least in certain areas. The negotiation's structure and especially the balance of power are thus significantly altered, not only for the different representative organizations of workers but within the framework of specific

33 Ruhs, M., "The rights of migrant workers: Economics, politics and ethics," ILR, 2016-2, vol. 155, p. 283.

34 Rodríguez-Piñero y Bravo-Ferrer, M., "El desplazamiento temporal de trabajadores y la Directiva 2014/67 relativa a la garantía de cumplimiento de la Directiva 96/71/CEE," DRL, 2016-5, p. 407; Guamán Hernández, A., "La propuesta de reforma de la Directiva 96/71 de desplazamiento de trabajadores en el marco del Plan de Trabajo de la Comisión Europea para el 2016", RDS, 2016-73, p. 113.

35 EuZA, 2016-2, Special topic: "Temporary Work," for all: Junker, A., "Arbeitnehmerüberlassung und Werkverträge - Der europäische Rahmen," p. 141.

36 Campling, L., Harrison, J., Richardson B. and Smith, A., "Can labour provisions work beyond the border? Evaluating the effects of EU free trade agreements," ILR, 2016-2, vol. 155, p. 357.

37 See Gottardi, D., "La contrattazione collettiva tra destrutturazione e ri-regolazione", LD, 2016-4, p. 877 and the essays published in the chapter "Il diritto del lavoro vivente: la contrattazione collettiva" of the same issue.

38 Sometimes the planes appear intertwined, Graeme, C., "Litigation as an alternative to collective bargaining", about "sleepover" cases in New Zealand, BCLR, 2016, iss. 92, p. 217. See too, Cialti, $\mathrm{H}$., "Solución a la pérdida de ultraactividad del convenio sin nuevo acuerdo: El caso francés," $D R L$, 2016-2, p. 173.

39 Jeammaud, A., "Contrat individuel de travail et accord collectif de travail," RDT, 2016-4, p. 228.

40 Mendoza Navas, N., "Los procedimientos de inaplicación de condiciones de trabajo al amparo de las decisiones de la Comisión Nacional Consultiva de Convenios Colectivos," RDS, n 74/2016, p. 61. 
companies. Indeed, at such a lower territorial level, the possibilities that entrepreneurs have to exercise influence in a much more decisive way multiplies exponentially. ${ }^{41}$

In regard to freedom of association and, more specifically, the right to strike, many articles revolve around the basic rights of action and conflict. ${ }^{42}$ Indisputably, this issue constitutes the main subject of articles, either because significant legal reforms have taken place (United Kingdom), ${ }^{43}$ or because of the decisive role of new judicial rulings (Canada). ${ }^{44}$ More specifically, the law imposes certain requirements to ensure that calls or proposals are legitimate and their effects are proportional, mainly through pre-strike ballots by all affected workers and by setting limits to guarantee the effectiveness of other rights for the rest of the citizens.

\section{CHALLENGES PRESENTED BY THE
CHANGING NATURE OF EMPLOYMENT}

More than 100 of the articles published in member journals during 2016 dealt with the challenges of regulating labor when the nature of employment is changing so rapidly. In broad terms, the articles dealt with two issues. First, what is actually happening in the labor market? How is the nature of employment changing and why? And second, what changes need to be made to labor regulation to ensure adequate worker protection in the face of these changes?

\section{A. - HOW IS THE LABOUR MARKET CHANGING?}

The literature has recognized for decades that the standard model of employment is under challenge. The standard model has been described in various ways, but the general picture is one of a long-term, full-time employee with a single employer. The employee is often unionized, usually male, fairly paid, with considerable job security, and with a complex array of job protections. The central problem presented by the changing nature of employment is that the framework of legal protections for workers was built with the

41 Cella, G.P., "Quale futuro per la contrattazione collettiva?," DLRI, 2016-2, vol. 38, p. 217.

42 Sädevirta, M., "Freedom of Association and the Right to Strike," EuZA, 2016-1, p. 445.

43 Moore, S., "'We Planned a Dispute by Blackberry': The Implications of the Trade Union Bill for Union Use of Social Media as Suggested by the BA-BASSA Dispute of 2009," ILJ, 2016, vol. 45, p. 251. In the same journal, see Dukes, R., "Pre-strike Ballots, Picketing and Protest: Banning Industrial Action by the Back Door?," iss. 3, p. 337.

44 Adams, R.J., "Bringing Canada's Wagner Act Regime into Compliance with International Human Rights Law and the Charter," CLELJ, 2016-2, vol. 19, p. 53. In the same review and volume, see Etherington, B., "The Right To Strike under the Charter after Saskatchewan Federation of Labour: Applying the New Standard to Existing Regulation of Strike Activity," 2016-2, p. 117 and Cavalluzzo, P., "The Impact of Saskatchewan Federation of Labour on Future Constitutional Challenges to Restrictions on the Right To Strike," CLELJ, 2016-2, vol. 19, p. 117. For reviews of other countries, see Peetz, D., "Industrial Action, The Right to Strike, Ballots and the Fair Work Act in International Context," AJLL, 2016-2, vol. 29, p. 133; same journal and volume, Creighton, B., "Strike Ballots and the Law in Australia," p. 154; Wilson, M., "Strike Ballots: The New Zealand Experience," p. 194; Benjamin, P., "Strike Ballots in South Africa," p. 210. 
standard model in mind. While the framework did a decent-enough job of providing legal protections for that category of worker, the nature of work has been shifting. ${ }^{45}$

A major focus of the scholarship in 2016 was on the wide variation in the models of employment that are taking the place of the standard model ${ }^{46}$. The changes are taking place on the employer-side, on the employee-side, and in the nature of the work itself. ${ }^{47}$

On the employer-side, several important and evolving changes were discussed in the literature. First, employers are "fissuring." The general idea here, named and well-described by David Weil, ${ }^{48}$ is that where in the past one employer might have employed all the workers at a particular site, now several employers may be in play.

A second related development is that the "employer" of the employee may not be the recipient and beneficiary of the worker's labors, but instead an intermediary employer who hires the employee and then contracts with the recipient employer to supply the worker. With some variation around the margins, this type of arrangement goes by many labels, including temporary agency work, ${ }^{49}$ personnel leasing (in Germany), ${ }^{50}$ payrolling (in the Netherlands), ${ }^{51}$ and portage salarial (in France). ${ }^{52}$ But like fissuring, it introduces the possibility and complications of a multi-party employment relationship rather than a twoparty one.

Third, an emerging category of "employers" claim not to be employers at all, but rather software platforms that merely connect available workers with those who are willing to purchase their services. Uber and Lyft, significant companies that connect drivers with people needing rides, are the prototypical examples. One could view this as another type of three-party arrangement, but here none of the parties are willing to accept the employer role.

There are other developments on the employer side of the employment relationship as well, but this should suffice to illustrate the nature and scope of the changes.

Similarly dramatic changes are taking place on the employee side of the employment relationship. One development is that employees are increasingly working away from the employer's premises. This has always occurred, of course; homework and telecommuting

45 It should be noted that the articles in member journals focused on labor regulation in developed economies where the worry is one of decline in labor standards and protections. Consequently, that is also the focus of this review. The new forms of work, however, are also very present in developing economies and the issues may be quite different there, especially if the new technologies permit rapid gains in labor productivity. See Evelyn Wamboye, Abel Adekola \& Bruno Sergi, "ICTs and Labour Productivity Growth in Sub-Saharan Africa," ILR, 2016, vol. 155, p. 231 (finding that new technologies provide significant boosts to labour productivity).

46 See the debate on the individual contract of employment in DRI 2016-3.

47 Since we are talking about a relationship, these categories tend to blend into each other, but it is useful to think about them separately.

48 The Fissured Workplace: Why Work Became So Bad For So Many and What Can Be Done to Improve It (2014).

49 Valerio de Stefano, "Introduction: Crowdsourcing, the Gig-Economy, and the Law," CLLPJ, 2016, vol. 37, p. 461.

50 Wolfgang Hamann, "The Draft Bill on the Modification of the Personnel Leasing Act and Other Acts," AuR, 2016, No. 4.

51 Johan P.H. Zwemmer, "Payrolling in the Netherlands," BCLR, 2016, vol. 94, p. 117.

52 Francis Kessler, "'Employees Without a Boss': Portage Salarial in France," BCLR, 2016, vol. 94, p. 103. 
(a dated phraseology) have existed for a long time. But modern information and communication technologies (ICT) have increased its incidence and created new problems. On new problems, for example, the issue of what to credit as work time has become increasingly complex as ICT makes it possible for employers to contact workers anywhere at any time, and expect prompt responses.

Another development is that workers often have more tenuous connections with their employers. The prototypical example of this is the so-called zero-hour contract in the United Kingdom through which employers agree to pay for work completed but make no commitments to provide any quantum of work (all the way down to zero hours, as the name implies). These contracts certainly help employers respond to changing demand for labor, but they increase the insecurity of workers and loosen the tie between employer and employee.

ICT makes it possible for these ties to become even looser. Crowd-funding is zero-hour contracts writ large. Employers offer large or small tasks (but usually very small tasks) on an electronic platform which provides access to workers willing to perform the tasks. The workers are often encouraged to compete against one another (sometimes by making the experience game-like) and they are usually paid very small amounts for each task. One way of viewing this is as a zero-hour contract with even weaker connections between employer and worker. (On the employer side of this, again, no one in this arrangement is willing to assume the label "employer." $)^{53}$

Finally, the nature of work itself is changing rapidly. An increasing amount of work is in the new "gig economy":

Named for one-time performances of musicians, the "gig economy" typically has performers bring their own equipment, set their own schedule and hours, and provide a service directly to the consumer while a third-party intermediary promotes the service, provides the platform through which the performer and consumer interact, and collects the payment from the consumer, taking a percentage for itself and transmitting the rest to the performer. The performer needs the connections, convenience, and recognition the intermediary provides, and the intermediary needs the performer to provide the service. It is this independent yet symbiotic relationship that distinguishes employment relations in the "gig economy" from standard employee or independent contractor relationships. ${ }^{54}$

This category of work is rapidly increasing for two principal reasons: (1) an increasing amount of work is cognitive only and (2) because of computerization, it can be done anywhere, anytime. A unique and somewhat troubling aspect of this type of work is that it can occur (and usually occurs) with no direct human interaction at all; both the employer and the employee interact only with their computers. ${ }^{55}$

53 See Wolfgang Daubler \& Thomas Klebe, "Crowdwork: datore di lavoro in fuga?," DLRI, 2016, vol. 151, p. 471.

54 Steven L. Willborn, et al., Employment Law: Cases and Materials 38 (2017).

55 For a good overview, see Luka Tičar, "The Impact of Digitalisation on the Emergence of New Forms of Work," E\&E, 2016, vol. 16, p. 241; Trillo Parraga, F., "Economía digitalizada y relaciones de trabajo", RDS, 2016-76, p. 59. 
As noted, these types of changes and how labor and employment law should respond to them were among the most discussed topics in the member journals of the IALLJ in 2016. But how prevalent are these types of changes in the nature of employment? On the one hand, the percentage of workers engaged in these types of alternative work arrangements is still much smaller than the percentage of workers in more traditional employment relationships. A recent study in the United States, for example, found that the overall percentage of workers engaged in some type of alternative work arrangement was 15.8 percent. More specifically, the study found that 3.1 percent of workers were hired through contract companies and only 0.5 percent of workers provided services through on-line intermediaries (such as Uber or Amazon Mechanical Turk). This makes it seem as if the journals' focus on alternative work arrangements and especially the high level of attention given to employment obtained through on-line intermediaries is misplaced. On the other hand, the study found that an astounding 94 percent of net employment growth in the United States from 2005 to 2015 occurred in alternative work arrangements. ${ }^{56}$ The clear implication is that while the future of employment is not yet with us, it is arriving fast. Perhaps, the journals are merely ahead of the curve.

\section{B - HOW SHOULD LABOR REGULATION ADJUST TO THESE LABOUR MARKET CHANGES?}

The articles in member journals during 2016 discussed many ways in which states are re-thinking labor regulation to address these changes in the nature of employment. ${ }^{57}$

One area of inquiry is how to classify workers who fall outside the standard model of employment. Traditionally, workers have been divided into two principal categories: "employees" and "independent contractors." One issue relates to employers either structuring employment to avoid the protections of labor and employment law or, worse, intentionally misclassifying workers to avoid those obligations. On misclassification, several articles this year talked about the problem of "bogus" self-employment ${ }^{58}$ and "hidden" employment, ${ }^{59}$ especially with respect to new forms of employment. But the deeper problem with many of these new forms of employment is not so much misclassification as it is that workers do not fit cleanly into either category. The problem was stated well by an American judge who in trying to decide whether Lyft drivers were employees said that the problem is that the jury "will be handed a square peg and asked to choose between

56 Lawrence F. Katz \& Alan B. Krueger, "The Rise and Nature of Alternative Work Arrangements in the United States, 1995-2015," NBER Working Paper Series, 2016, N․ 22667.

57 These articles tend to assume that labor law must respond to these changes in the economics of work, and suggest ways of doing so. Generally, the articles do not address broader issues about the proper relationship between economics and labor law. For example, to what extent should labor law accept these changes in the economics of work and attempt to facilitate them or should labor law stand as a bulwark against many of them as an expression of deep-seated societal values? These broader issues were discussed well in the $30^{\text {th }}$ anniversary issue of $L D$. See Valerio Speziale, "La trasformazione del diritto del lavora," LD, 2016, iss. 4, p. 719; Vincenzo Bavaro, "Apppunti su scienza e politica sul diritto del lavoro," LD, 2016, iss. 4, p. 707.

58 Tamás Gyulavári, "Civil Law Contracts in Hungary," BCLR, 2016, vol. 94, p. 79, 81; José João Abrantes \& Rita Canas da Silva, "New Forms of Employment in Portugal," BCLR, 2016, vol. 94, p. $313,314$.

59 Gaabriel Tavits, "New Forms of Employment in Estonia," BCLR, 2016, vol. 94, p. 193, 196-97. 
two round holes." 60 The tests courts have developed over decades to identify employees and distinguish them from other categories of workers simply do not apply very easily to fissured employment or to many forms of ICT-related work. ${ }^{61}$ The courts have been struggling to classify these forms of work as either employment or self-employment when neither category seems precisely right.

Another approach is to create a square hole for that unusual peg, for the new category of emerging workers. This category would be not quite an employee and not quite an independent contractor, but something in between. Instead of an independent contractor, the new category can be thought of as a dependent contractor. This category would be entitled to some but not all the labor protections available to full-fledged employees. Thus, a proposal in the United States would protect this category of workers from discrimination and provide them with insurance for workplace injuries, but would not require them to be paid a minimum wage or obtain health insurance. ${ }^{62}$ With some variation, this general approach has been implemented in a number of countries under different names, such as auto-entrepreneur (in France), ${ }_{1}^{63}$ para-subordinate (in Italy), ${ }^{64}$ economically dependent employees (in Hungary), ${ }^{65}$ and economically dependent autonomous employees (in Spain). ${ }^{66}$ While the approach is spreading, not everyone thinks it is a good idea. Valerio de Stefano, for example, thinks it is overly difficult to define the class of workers who would fit into the limited-protection category and that the category can operate as an obstacle to achieving full labor protections. ${ }^{67}$

The first two ways of dealing with new forms of work attempt to re-work general rules that can apply across broad categories of employment relationships. A third approach is to identify particular employment relationships that pose new and special problems and develop special employment protections for those relatively narrow categories. An emerging example of this is "voucher" employment. This system, used in several countries, permits an "employer" to buy a voucher to pay a worker. The voucher includes payments for governmental programs, such as social security. The system is generally available only to certain types of occupations (such as home workers) which for various reasons tend to

60 Cotter v. Lyft, Inc., 60 F. Supp. 3d 1067, 1081 (N.D. Cal. 2015).

61 Jeremias Prassl published an important book in 2015 that described well the problems of identifying employees and proposed a solution focusing on employers. THE CONCEPT OF THE EMPLOYER. The book was reviewed several times in member journals during 2016. See, e.g., Judy Fudge, "The Concept of the Employer," ILJ, 2016, vol. 45, p. 270; Luca Ratti, "Intorno al-i concetto-i di datore di lavoro. A proposito di The Concept of the Employer di Jeremias Prassl," DLRI, 2016, vol. 150, p. 381.

62 Seth Harris \& Alan Kruger, A Proposal for Modernizing Labor Law for Twenty-First-Century Work: The "Independent Worker" (The Hamilton Project 2015).

63 Jean-Emmanuel Ray \& Jacques Rojot, "The Fissured Workplace in France," CLLPJ, 2016, vol. 37, p. 463.

64 Breen Creighton \& Shae McCrystal, "Who is a "Worker" in International Law?," CLLPJ, 2016, vol. 37, p. 691.

65 Tamás Gyulavári, supra note 53, at 87.

66 Joaquín García Murcia \& Iván Rodríguez Cardo, "New Forms of Employment in Spain," BCLR, 2016, vol. 94, p. 349, 352-53.

67 Valerio de Stefano, "The Rise of the 'Just-in-Time Workforce': On-Demand Work, Crowdwork, and Labor Protection in the 'Gig-Economy,' CLLPJ, 2016, vol. 37, p. 471, 494-99. 
operate outside the normal employment system in the absence of vouchers. ${ }^{68}$ Another approach is to deal with individual discrete problems presented by new forms of work. For example, ICT permits employers to reach out to call employees to work at any time, so it increases the number of issues presented by on-call time. Similarly, since ICT permits workers to work anywhere at any time, it also makes it more difficult to account for time actually worked. Neither of these are new problems, but ICT increases their incidence and salience. As a result, many countries have re-worked their rules on these topics; ${ }^{69}$ France has gone the furthest in this regard with their recent "right to be de-connected" law. ${ }^{70}$

On the other side of the relationship, a number of articles also dealt with the issue of what to do with a fissured or disappearing employer. The central problem here is how to hold employer's responsible for complying with employment law obligations when their relationship with workers is distant and fragile. A number of articles discussed ways in which the laws are adjusting to address this issue. One option is to expand the concept of joint employment so that more than one employer may be responsible for ensuring compliance when several are involved in the employment relationship. ${ }^{71}$ Alternatively, instead of joint employment which holds all employers responsible for all employment-related duties, another approach would be to allocate responsibilities to particular employers depending on their particular relationship to the worker. Thus, the hiring employer might be responsible for hiring duties, the employer that manages the employee day-to-day might be responsible for duties at the worksite, etc. ${ }^{72}$

An overriding issue in the legal response to new forms of employment is whether these are really new and unique problems, or whether they are slightly modified forms of problems labor regulation has always had to face. Matthew Finkin argues that while we can gain insight from pastexperiences, the regulatoryproblemsare "genuinely new" because computerization combined with the cognitive nature of the work transforms local markets into global ones, which are much more difficult to regulate. ${ }^{73}$ Perhaps. Or perhaps there have been other eras during which rapid change and globalization posed special challenges to labor regulation and we need to focus our attention on lessons from those eras. ${ }^{74}$ But whether new or old, there can be no doubt that the challenges to labor regulation are complex and difficult.

68 Several countries in Europe have implemented voucher systems. Symposium, "New Forms of Employment in Europe," BCLR, 2016, vol. 94, p. 1, 145 (Austria), 154 (Belgium), 231 (Greece), 34546 (Slovenia), 364 (Turkey).

69 See Bernd Waas, "New Forms of Employment in Germany," BCLR, 2016, vol. 94, p. 223, 224-25.

70 Ch. Mathieu et al., "Droit a la Déconnexion, Santé au Travail," 2016, RDT, iss. Oct.

71 See Daniela Izzi, "La responsabilità solidale a tutela del lavoro esternalizzato: qualche spunto dal diritto dell,Unione europea" LD, 2016-1, p. 35.

72 See Jeremias Prassl, "Uber, Taskrabbit, and Co.: Platforms as Employers? Rethinking the Analysis of Crowdwork," CLLPJ, 2016, vol. 37, p. 619.

73 "Beclouded work, Beclouded Workers in Historical Perspective," CLLPJ, 2016, vol. 37, p. 603, 617-18.

74 See, e.g., DANIEL T. Rodgers, Atlantic Crossings: Social Politics in a Progressive Age (1998)(reviewing social movements from the 1870 s to the 1940 s as they responded to increased globalization and rapid technological change); John Fabian Witt, The Accidental Republic: Crippled Workmen, Destitute Widows, and the Remaking of American Law (2004) (reviewing the origins of workers' compensation systems in the United States as railroads changed the geography and technology of legal regulation of accidental injury). See Polonca Končar, Digitalisation - The Challenges of Labour Law, E\&E, 2016, vol. 16, p. 257 (labour law has always evolved and adapted to change, including technological change). 


\section{|| - WAGES, POVERTY AND INCOME ISSUES}

Even though the question of poverty is far from a new concern for labour law and social security law researchers, it is worth pointing out the importance that the IALLJ authors granted to this topic in 2016. We would like to underline the two perspectives which particularly interested the authors on the question of poverty: 1) different and (relatively) new types of precarious workers and 2) questions about wages. The context of these works are, partly, a perfect extension of those of earlier years - the negative consequences of the 2008 financial and economic crisis and of the labour law and social security system reforms made in response to the crisis. ${ }^{75}$ There are also other factors which gave rise to these IALLJ works about poverty and wages, such as the increase of activities on the borderline between paid work and other activities, as well as the introduction of a national legal minimum wage in Germany, the idea of a European minimum wage, and the increasing and intensifying debates on the "capability approach." Let us examine the IALLJ works of 2016 on these questions in this order: precarious works; diverse questions about wages; issues relating to welfare schemes, including the basic income benefit.

\section{A - POVERTY, PRECARIOUS WORK, AND THE WORKING POOR}

\section{1 - POVERTY AFTER THE 2008 FINANCIAL CRISIS}

The 2008 financial crisis hit countries in an imbalanced way. Among the European countries, the poverty rate of the population in severe material deprivation increased dramatically in some countries (Spain, Greece, Ireland and Italy), while other countries - particularly, most of the former EU 15 member countries - did not experience a big change. ${ }^{76}$ This context can explain the strong interest of Italian IALLJ authors in the poverty question, ${ }^{77}$ as well as in the social policy reforms which had been implemented, at least partly in response to the increase in the poverty rate. The Italian scholarship on poverty paid special attention to family and regional perspectives: many countries (including Italy) addressed questions on the working poor and precarious workers, but in Italy there was special concern with the high poverty rate of children, especially in the southern part of the country. ${ }^{78}$ This characteristic might partly explain the strong interest of Italian authors in

75 On the consequences of the financial and economic crisis, it should be noted that an Italian author discusses a new and rather positive trend from the perspective of protecting workers' rights - a shift of Italian constitutional judges from an emergency approach to restrict worker social rights towards an attitude of restoration of the social rights of workers. Giancarlo Ricci, "I diritti sociali fra politiche di austerità e ripresa economica," DLM, 2016-1, p. 65.

76 ECFIN Economic Brief, 2014, iss. 31, p. 3.

77 Chiara Saraceno, "Povertà ed esclusione sociale oggi in Italia: cause e possibili rimedi," RGL, 20164, p. 717; Guiseppe Bronzini \& Piera Campanella, "Il lavoro tra bisogno e libertà: nuove povertà prospettive di inclusione sociale reddito e attivazione: Introduzione," RGL, 2016-4, p. 687. See also Matteo Jessoula, "Italy's winding road towards a national minimum income scheme," ESPN Flash Report 2016/60.

C. Saraceno, op. cit. 
improvement of the national welfare system (see section c below) which can directly and exhaustively cover all citizens in poverty throughout the nation. ${ }^{79}$

\section{2 - DIFFERENTTYPES OF PRECARIOUS WORKERS}

One approach of authors in tackling the question of poverty and low income was to view it from the perspective of different types of precarious work with an insufficient level of wages.

The issue of precarious employment has been treated repeatedly by IALLJ authors after the recession and in the context of the rapid spread of the flexibility (flexisecurity) policy. ${ }^{80}$ In Europe, except in the Nordic countries, the flexibility policy has resulted in an increase in the number of poor workers. A special issue was devoted to the consequences of this policy in 2016;81 one article in the issue follows and analyses the growth of precarious employment in Europe (the former $15 \mathrm{EU}$ member countries) as a consequence of this policy. ${ }^{82}$ The article, by focusing on two dimensions of precarious employment - insecurity and poverty (low wages ${ }^{83}$ ) - shows that the proportion of low-wage workers is high in southern European countries (Spain, Greece, Italy and Portugal), as well as in countries with more deregulated labour markets (Germany, Ireland, the Netherlands and the United Kingdom), while the southern European countries are also characterized by high levels of insecurity (measured by atypical employment). ${ }^{84}$

Several issues related to precarious workers were of particular interest to IALLJ authors in 2016: issues related to education, personal life, independent work, and activities related to welfare allocation. ${ }^{85}$

First, some authors paid particular attentions to the activities between education and work, which are more and more frequent in today's labour market, particularly among young workers, across the developed world. These are often called "traineeships"86 or "internships. ${ }^{87}$ Even though these activities can be extremely useful for both workers and

79 Another context for this interest in welfare systems might be the lack of a national and universal measure to combat poverty in Italy. On this point, see Stella LaForgia, "Le politiche regionali di contrasto alla povertà e di inserimento sociale e lavorativo," RGL , iss. 3, p. 574.

80 See S. Borelli \& H. M. Hohnerlein, "Retrospective Overview of 2013 - Comparative labour law literature," RDCTSS, 2014/3, p. 218; M. Aimo \& D. Izzi, "Retrospective Overview of 2012 Comparative labour law literature," RDCTSS, 2013/3, p. 185.

81 ILR, 2016, vol. 155, no. 4 (Special Issue: "The Age of Flexibility").

82 T. Gutiérrez-Barbarrusa, "The growth of precarious employment in Europe: Concepts, indicators and the effects of the global economic crisis," ILR, 2016, v. 155, no. 4, p. 477.

83 The author adopts the Eurostat definition of low wages (wages that amount to two-thirds or less of national median hourly earnings).

84 The author compares the situations in 1995-2007 with those in 2008-2015. In addition to the influence of deregulation policy, the author points out the impact of the expansion of the EU in 2004 and 2007, particularly for the increase of poverty in Germany and the United Kingdom.

85 Among the other types of precarious work, undeclared work has also drawn the attention of some authors. See Marta Giaconi, "Le politiche europee di contrasto al lavoro sommerso. Tra (molto) soft law e (poco) hard law," LD, 3-2016, p. 439; Simone Varva, "Undeclared work e Unione europea, ultimo atto: una "piattaforma europea" per contrastare il lavoro sommerso," LD, 3-2016, p. 461.

86 Rosin A., "Precariousness of Trainees Working in the Framework of a Traineeship Agreement," IJCLLIR, 2016, vol. 32, iss. 2, p. 131.

87 R. Owens R. \& A. Stewart, "Regulating for decent work experience: Meeting the challenge of the rise of the intern," ILR, 2016, vol. 155, iss. 4, p. 679. 
employers, they can produce situations of exploitation when the employers replace what might previously have been paid, entry-level jobs. They can also produce unjustifiable conditions for the trainees when, as is the case in many countries, there is not sufficient regulation for the protection of the collective and individual rights of trainees. The EU Council has already been aware of this question and adopted a recommendation on a quality framework for traineeships in 2014. ${ }^{88}$ The IALLJ authors, presenting the situations of EU law and regulations as well as those of certain EU and non-EU countries (United States, Australia, United Kingdom, Finland, France and Estonia were chosen by the authors), share an understanding that the European as well as individual countries' laws and regulations are lacking sufficient protections for trainees. France's legislative efforts to protect trainees (by the so-called "Cherpion Law"89) are appreciated positively by authors as an exception, even if the lack of monitoring and sufficient enforcement is pointed out. ${ }^{90}$

Second, a special issue was published about workers who are required to be "available over and above the time they spend at work."191 For certain workers (casual and on-call workers but also full-time or part-time workers who are regularly required to work beyond the agreed work hours), work hours and work schedules have become more and more unpredictable, since they need to adapt to the variable production needs of employers. ${ }^{92}$ A study about home support services networks in Quebec, Canada, shows that these new types of work are often practiced by female workers, and result in precarious and low-wage work. ${ }^{93}$

Third, as we have already examined ${ }^{94}$ so-called " crowd work" has also attracted a lot of interest from IALLJ authors in 2016. This kind of work can also be seen as a new type of precarious work, as presented by an article based on an ILO investigation. ${ }^{95}$ The abovecited article proposes to ensure a minimum-level wage for this kind of work, in maintaining the piece-rate system. The problem also overlaps with the second question (fixing the limits of work time) because these workers often spend a lot of time on line, trying to catch a better job when it appears. ${ }^{96}$

Authors also tackled another rarely discussed question about the precarious status of those who participate in workfare programmes in the UK and the Netherlands, two countries

88 The ILO defines a traineeship as "a limited period of work practice, whether paid or not, which includes a learning and training component, undertaken in order to gain practical and professional experience with a view to improving employability and facilitating transition to regular employment."

89 LOI n² 2011-893 du 28 juillet 2011 pour le développement de l'alternance et la sécurisation des parcours professionnels.

90 R. \& A. Stewart, op. cit., p. 689.

91 IJCLLIR, 2016, vol. 32, iss. 3. A theoretical framework for this kind of work is proposed in the first article of the special issue. Émile Genin, "Proposal for a theoretical framework for the analysis of time porosity," p. 280.

92 Guilaine Valée, "Employees' obligation to be available to Employers: A (New) Pathway to Precariousness or Source of Flexibility?," IJCLLIR, vol. 32, iss. 3, p. 275.

93 Louise Boivin, "'Just-in-Time' Labour: The case of networks providing home support services in Quebec," IJCLLIR, 2016, iss. 3, p. 301.

94 See supra, text \& notes at nn. 42-69.

95 Janine Berg, "Income Security in the On-Demand Economy: Findings and Policy Lessons from a Survey of Crowdworkers," CLLPJ, 2016, vol. 37, p. 543.

96 J. Berg, op. cit., p. 561. 
which have been leading figures of the workfare politiques in the European and other developed countries' activation programmes. ${ }^{97}$ In the context of continuous development of the activation politique in the welfare schemes in many countries, this article might also inspire comparative research in other countries' labour and welfare law.

As the concept of precarious worker often implies low income (and it is also the case for the types of precarious worker that we presented above), the question of precariousness overlaps largely with that of the working poor, though, the latter question itself was explored less often by IALLJ authors. ${ }^{98}$ As we will see, however, many authors were interested in diverse questions about wages, often in relation to the poverty issue.

\section{B - WAGES, MINIMUM WAGES AND LIVING WAGES}

Diverse questions concerning wages interested a lot of IALLJ authors in 2016, particularly the question of the minimum wage. Fixing a minimum wage can sometimes be considered one of the solutions to the poverty problem, as it can increase the income of precarious workers, who are often in poverty. It is also considered to be an economic policy which supports and encourages domestic consumption and thus contributes to economic development. It is therefore logical that after the 2008 global economic and financial crisis, the question of wages has been considered to be pressing by researchers in a lot of countries on different continents but also by international organizations. ${ }^{99}$ The introduction of a legal minimum wage in Germany ${ }^{100}$ and the debates on the possibility of a European minimum wage $^{101}$ have strengthened this interest, particularly in Europe. In the European Union context, the minimum wage might also be considered to be a tool to realize a fair competitive environment from a labour costs perspective. Finally, a relatively new perspective has also been present concerning the minimum level wage: the concept of a "living wage." The authors who argue for a living wage focus on human rights and social justice to determine the minimum wage level which should be guaranteed to all workers, considering that the "minimum wage" as it is generally designed today is insufficient from this point of view.

\section{1 - THE MINIMUM WAGE}

Around the minimum wage, numerous questions can be discussed: its level, process for determining (by which norm? Who decides?), effects on the labour market, effectiveness, and so on. Let's see how these topics were discussed by IALLJ authors, putting aside for the moment the topic of the appropriate level of the minimum wage (which we will discuss

97 Amir Paz-Fuchs \& Anja Eleveld, "Workfare revisited," ILJ, 2016, vol. 45, p. 29.

98 See Calvo Gallego, F.J., "Trabajadores pobres y pobreza de los ocupados: Una primera aproximación," $T L, n^{\circ} 134 / 2016$, p. 63. The difficulty of defining the "working poor" which is emphasized in this article might be one of the reasons for the (relative) reluctance of legal researchers to address this topic.

99 COM (2012)173, p. 9, Stuart C. Carr, Jane Parker, James Arrowsmith, \& Paul A. Watters, "The living wage: Theoretical integration and an applied research agenda," ILR, 2016,, vol. 155, iss. 1, p. 1 (see particularly the introduction to the article for the recent debates about wages).

100 Thomas Lakies, "Ein Jahr gesetzlicher Mindestlohn - gelöste und ungelöste Rechtsprobleme", AUR, 2016 - 1, p.14. Hendrik Pütz, "Zur Vergütungspflicht von Überstunden durch das Mindestlohngesetz", AUR, 2016 - 5, p. 186. Patrick Rémy, "La loi allemande sur le salaire minimum: le SMIC en Allemagne?," RDT, 2014, p. 774.

101 See, for example, Schulten, Thorsten, Torsten Muller, \& Line Eldring. "Pour une politique de salaire minimum européen : perspectives et obstacles," La Revue de I'Ires, 2016, vol. 89, no. 2, p. 89. 
later, together with the living wage).

About the process of decision, from the perspective of comparative labor law, it is essential to take in consideration the role of social partners on the question of wages regarding the legal minimum wages (including the European level social partners with respect to the European regulations). An Austrian author discusses this point, in making comparisons between German and Austrian laws and the social partners' relationships, claiming that in the countries where collective bargaining coverage is high, the collectively bargained minimum wage can guarantee decent minimum wages for the employees, while, at the same time, guaranteeing a minimum of contractual freedom for the parties to the employment relationship. ${ }^{102}$

The distribution and equalizing effects of the minimum wage interested the Latin American authors. The article about the distribution effects of the increase in the real value of the minimum wage in Argentina, Brazil, Chile and Uruguay, shows that the distributional effects were confirmed in three of these countries (allexcept Chile). ${ }^{103}$

Various factors affect whether the minimum wage can be effectively enforced.. An author points out, examining the situations in Latin American countries (Chile, Costa Rica, Peru and Uruguay) that the minimum wage needs to be accompanied by an efficient labour inspection system, particularly when the minimum wage is very low or very high relative to average wages of the countries. ${ }^{104}$ It was also pointed out by an Austrian author that the collectively agreed sectoral minimum wage is more easily applied by employers than the statutory universal minima. ${ }^{105}$

\section{2 - THE LEVEL OF THE MINIMUM WAGE AND A NEW ORIENTATION: THE LIVING WAGE}

One of the major questions about the minimum wage is, of course, what the level should be: what level is necessary and sufficient as a minimum standard of wages? And this question cannot be separated from the objective of the minimum wage - what are we trying to accomplish in guaranteeing the minimum standard of wages? Even though, as we mentioned above, the minimum wage can have multiple dimensions - workers' rights, economic policy, ensuring fair competition between employers, etc., the IALLJ authors treated this topic almost entirely from the first perspective - the workers' human and fondamental right, as well as, by extension, a certain social justice. In an article inspired by the idea of a European minimum wage and the German minimum wage scheme, an author discusses a "minimum income through wage," claiming that the wage should guarantee a "fair and sufficient reward for work." 106

102 Elisabeth Brameshuber, "'Basic Income' from Wages: Freedom of Contract versus Statutory Minimum Standards," ELLJ, 2016, vol. 7, p. 206. The author also claims that in this situation, the general wage level is relatively high. P. 227.

103 Roxana Maurizio \& Gustavo Vázquez, "Distribution effects of the minimum wage in four Latin American countries: Argentina, Brazil, Chile and Uruguay,"ILR, 2016, vol. 155, p. 97.

104 Andres Marinakis, "Non-compliance with minimum wage laws in Latin America: The importance of institutional factors," ILR, 2016, vol. 155, p. 133.

105 E. Brameshuber, op. cit., pp. 226 and 227.

106 E. Brameshuber, op. cit. 
And from this point of view, a new vision of the minimum wage - called (or not) a "living wage $^{\prime \prime 107}$ - which should be fixed at the level that guarantees human dignity and not only the pure and material survival of workers - has been proposed by certain authors. Behind this trend, we can observe the strong influence of the "capability approach,"proposed by Amartya Sen and Martha Nussbaum, ${ }^{108}$ a theory which interests a lot of labour law scholars as a "cornerstone for a renewed labour law."109

We also would like to add that in the articles debating the minimum standard for wages, different words are applied by different actors and authors, which are not always strictly defined and which can be used in different senses - "equitable,"110 "fair income," "sufficient reward for work," "basic income," "minimum wage (income)," "decent wages" or "amount of income ... to live in dignity," etc. ${ }^{111}$ Furthermore, when we discuss "income," it can be guaranteed either by wages alone or by both wages and social security. ${ }^{112}$ This point encourages us to examine carefully, when we discuss guaranteeing a minimum standard of wages, what exactly we are talking about. The complex and multifunctional character of the minimum wage that we discussed above also justifies this cautious attitude in the debates on the minimum wage.

\section{3 - OTHER QUESTIONS ABOUT WAGES}

The rising interest in the minimum wage might also increase our interest in different questions about wages in general. ${ }^{113}$ And particularly in relation to the debates about the European minimum wage, some questions will be worth discussing from a comparative perspective; for example, the question of the effectiveness of different norms concerning wages in general, ${ }^{114}$ the role of labour inspection, and the question of the definition of wages. About the latter, on a rather classical but yet always controversial question, one author examined in a comparative study the different treatments of "tips" in France, Germany and the United States. ${ }^{115}$

107 Stuart C. Carr, Jane Parker, James Arrowsmith \& Paul A. Watters, op. cit.

108 See, for example, Martha Nussbaum, (2011) Creating Capabilities: The Human Development Approach. Cambridge, MA: Harvard University Press.

109 Riccardo Del Punta, "Labour Law and the Capability Approach," IJCLLIR, 2016, p. 383.

110 E. Brameshuber, op. cit., p. 213.

111 According to the article about the living wage, this concept is related to the broader concept of "decent work" included and defined in the ILO's agenda. (see Stuart C. Carr et al., op. cit.). About decent work, see also Francesco D'Ovidio, "Il lavoro che verrà," RGL, 2016-4, p. 698.

112 E. Brameshuber, op. cit., p. 210.

113 The International Labour Review published a special issue on wages. 2016, vol. 155-1. Among other things, the issue includes an analysis of the inequality of wages in China. John Whalley \& Chunbing Xing, "Ownership restructuring and wage inequality in urban China," ILR, 2016, 155-1, p. 57 .

114 See the articles in vol. 37, iss. 2 of CLLPJ, as well as Renato Bignami \& Maria Cristina Serrano Barbosa, "La Inspección de Trabajo y el fraude salarial en Brasil: justicia al nivel de la calle, desarrollo y paz social", DRL, 2016-7, p. 686.

115 Matthew W. Finkin, "'The Kindness of Strangers': The Tip and the Minimum Wage in France, Germany, and the United States," IJCLLIR, 2016, vol. 32, iss. 1, p. 3. 


\section{C - BASIC INCOME AND WELFARE}

Even though the minimum wage can solve a part of the poverty problem, it is not, of course, a magical solution which automatically resolves all the poverty situations. First, the minimum wage is often set at an insufficient level to guarantee the living conditions beyond the bare poverty threshold. ${ }^{116}$ Moreover, if the minimum wage is fixed on an hourly basis, the minimum wage is not a solution to the problem of insufficient working time (typically this affects part-time workers with modest incomes). And needless to say the minimum wage can only cover the working population and the problem of poverty of those who don't work or who are not of working age can never be totally resolved by a minimum wage (or living wage) scheme.

As a result, different types of welfare schemes - social assistance as well as unemployment benefits - also interested IALLJ authors as possible solutions to the poverty issue. ${ }^{117}$ In the general and continuous trend of workfare policy in these welfare schemes in a lot of countries, an opposite direction was examined by some authors as another possible option - universal basic income. ${ }^{118}$ Authors, in presenting different types of universal basic income, pointed out the limits of the universal income concept: its uniformity and the low level of allocation, compared to the existing social security benefits, which vary according to the real necessity of individuals. According to the authors, the concept of universal basic income is presented in this article as one which can cover diverse types of income guarantee systems, including a lot of existing social allocations. ${ }^{119}$

116 E. Brameshuber, op. cit., p. 210.

117 See, for example, Makoto Arai, "Gesetz über die Soziale Wohlfahrt und Rechtsschutz für Nutzer von sozialen Wohlfahrtsdiensten," ZIAS, 2016, Heft 1, 30. Jahrgang, 2016, p. 3 ; Ute Kötter , "Die Sozialhilfe im Recht der Europäischen Union - immer noch eine Randexistenz oder auf dem Weg zu einem „Europäischen Sozialhilferecht"?," ZIAS, 2016, Heft 1, 30. Jahrgang, 2016 p. 98 ; Silvia Spattini "Sostegno al reddito dei disoccupati nella legislazione nazionale," RGL, 2016-3, p. 550561 ; Natalia Paci, "Disoccupazione e strumenti di sostegno del reddito nel Jobs Act?," RGL, 20164, p. 781 ; García Viña, Jordi, "La protección por desempleo en España" DRL, Issue n 5, p. 425; B. Suárez Corujo, "El colapso de la protección por desempleo en tiempos de crisis," DRL, 2016, Issue $\mathrm{n}^{\circ} 7$, p. 655; Antonella Occhino, "Il sostegno al reddito dei lavoratori in costanza di rapporto tra intervento pubblico e bilateralità," DLM, 2016, vol. 3, p. 499.

118 An Italian author claims that the basic income should be considered to be a constitutionally necessary tool in interpreting the Italian Constitution. Chiara Tripodina, "Povertà e dignità nella Costituzione italiana: il reddito di cittadinanza come strumento costituzionalmente necessario," RGL, 2016-4, p. 732.

119 Grega Strban, Renata Mihalič, Prednosti in pomanjkljivosti različnih oblik univerzalnega temeljnega dohodka, E\&E, Vol. 16, No. 1/2016, p. 9. 2 In this article, the original and core form of a universal basic income is defined as a non-selective, long-lasting, individual and completely unconditional income, independent of the social and economic situation of the beneficiary and the origin of the social situation. 